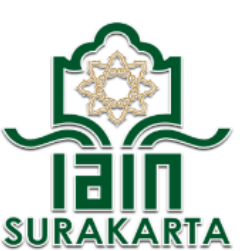

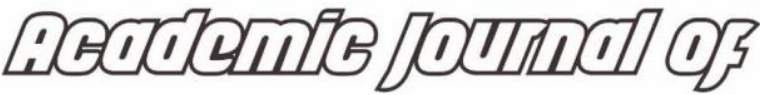

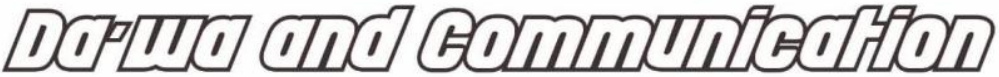

\section{RESEPSI KOMODIFIKASI HALAL PADA IKLAN JILBAB ZOYA}

\author{
Juri Lestari \\ Kamila Adnani \\ IAIN Surakarta
}

\section{Keywords:}

Reseption;

Commodification;

Halal;

Advertisement;

Hijab

\begin{abstract}
Giving halal certification for many products is a guarantee that products is safe for consumption by a Muslim people. But media tend to using religion value to get a big commodity that profitable for company, or change the using value of religion to economic value. This research is a study about audience of television advertisement with the reception approach. This research is for knowing how are the Solo Hijabers community members meaning to Zoya Hijab advertisement. This research is using a qualitative method. Data analysis that using is Reception by Stuart Hall (encoding-decoding) with using three kind of analysis, dominant hegemonic position, negotiated position, and oppositional position. The result that researcher get is just showing two types, that is hegemonic dominant and negotiation. While the opposite position not happen to Hijabers Solo Community. In this research also found interesting something, although informant nothing have an attitude, meaning, and act the same way. They are still agree of hijab Zoya distribution in the market. Even they want to buy or using that hijab. Without they realize, they agree halal value to the Zoya hijab advertisement is a form of commodification.
\end{abstract}




\section{Kata kunci:}

Resepsi;

Komodifikasi;

Halal; Iklan; Jilbab

\begin{abstract}
Abstrak
Pemberian sertifikasi halal dalam iklan cenderung menggunakan nilai agama sebagai komoditas yang menguntungkan perusahaan. Penelitian ini merupakan studi tentang audiens iklan televisi dengan pendekatan resepsi. Penggunaanya bertujuan untuk mengetahui bagaimana pemaknaan Anggota Komunitas Solo Hijabers terhadap komodifikasi halal pada iklan Jilbab Zoya. Metode penelitian yang digunakan adalah kualitatif. Analisis data yang digunakan adalah Resepsi Struat Hall (encoding-decoding) dengan menggunakan tiga dimensi analisis posisi dominan hegemoni, posisi negosiasi, dan posisi oposisi. Hasil penelitian menunjukan penerimaan pesan setiap audiens tergantung pada latar belakang budaya dan pengalaman hidup audiens itu sendiri. Hal ini menunjukkan bahwa audiens tidak hanya menerima pesan yang disampaikan oleh pengirim pesan, tetapi juga bisa mereduksi pesan yang disampaikan. Hasil penelitian yang diperoleh peneliti hanya menunjukkan dua tipe yaitu dominan hegemonik dan negosiasi. Penelitian ini juga menemukan sesuatu yang menarik, meskipun informan tidak memiliki sikap, pemaknaan, dan bertindak dengan cara yang sama. Mereka tetap mendukung kebijakan pihak Zoya, yang menyatakan bahwa jilbab Zoya halal dan mendukung peredarannya di pasaran. Bahkan mereka ada keinginan membeli atau memakai jilbab tersebut. Di sini, tanpa sadar mereka menyetujui nilai halal pada iklan jilbab Zoya adalah bentuk komodifikasi.
\end{abstract}

\section{PENDAHULUAN}

Iklan adalah setiap bentuk bayaran untuk mempresentasikan, mempromosikan suatu ide, barang, atau jasa secara non personal oleh sponsor yang jelas (Biagi, 2010). Selain sebagai hiburan sebenarnya iklan memiliki fungsi yang kasat mata diantaranya persuasi, membentuk sikap, membantu perkembangan budaya konsumen, dan sebagai pesan yang principal (Silverblatt dalam Subandy,2014).

Iklan televisi adalah realitas sosial bentuk media massa, yang tanpa disadari dapat menguasi jalan pikiran masyarakat. Berbicara soal iklan maka juga berbicara soal periklanan. Periklanan sendiri adalah seluruh proses yang meliputi penyiapan, perencanaan, pelaksanaan dan pengawasan iklan. Proses di mana ada timbal balik antara media dengan produk sponsor yang sama-sama akan menguntungkan. Media yang menjadi sasaran promosi produk iklan di antaranya adalah televisi, radio, bioskop, surat kabar, tabloid, baliho, Instagram, dan lain sebagainya. Pada kasus penyiaran iklan biasanya cenderung menyajikan good news supaya menjadi pilihan bagi yang melihatnya. Media menyiarkan iklan tujuan 
utamanya mencitrakan atau branding bahwa produk yang diiklankan baik. Salah satu media massa yang sangat baik membentuk citra pada suatu produk adalah iklan televisi. Iklan televisi dalam strategi pemasaran, bertanggung jawab dalam membentuk budaya masyarakat konsumen. Membangun standar perilaku dan gaya hidup, yang mana sangaja dirancang untuk membentuk standar tertentu yang menjadi tren dalam masyarakat. Menariknya suatu iklan, masyarakat kerap tidak menyadari bahwa ada sesuatu nilai, budaya, atau agama yang dikomodifikasi dalam bentuk iklan.

Mayoritas penduduk Indonesia adalah muslim, untuk itu agama kerap terlibat dalam media. Masyarakat sering kali tidak menyadari bahwa ada suatu nilai, budaya, atau agama yang dikomodifikasi dalam bentuk iklan. Pemberian sertifikasi halal untuk berbagai produk adalah jaminan bahwa produk aman dikonsumsi seorang muslim. Namun media cenderung menggunakan nilai agama sebagai komoditas yang menguntungkan perusahaan, atau mengubah nilai guna produk menjadi nilai ekonomis. Sebagai negara mayoritas penduduknya menganut Islam, sesuai sensus tahun 2010. Sekitar $87,2 \%$ atau 207,2 juta orang dari jumlah total penduduk Indonesia dari 237.641.326 . Dalam pusaran media, banyak penggunaan nilai agama yang dibalut kapitaslisme dan dijadikan alat komoditas. Sekarang perkembangan industri- industri yang menyasar segmen muslim tumbuh dengan cepat. Terbukti dengan munculnya fenomena komersialisai agama berupa fenomena berlebel produk-produk halal.

Di Indonesia, seluruh produk yang dipasarkan bisa mendapat sertifikasi halal. Pengaturan penggunaan produk halal itu sendiri, yaitu sertifikasi dan labelisasi. Sertifikasi halal adalah fatwa tertulis MUI yang menyatakan kehalalan suatu produk, sesuai syariat Islam melalui pemeriksaan yang terperinci oleh LP POM MUI. Beredarnya produk-produk halal didasari adanya Undang-undang No. 33 tentang Jaminan Produk Halal (JPH), tahun 2014. UU ini mendorong semua produk yang beredar di Indonesia memiliki sertifikasi halal dari Badan Penyelenggara Jaminan Produk Halal (BPJPH) dan Majelis Ulama Indonesia (MUI). Pada 2019 UU JPH akan diberlakukan dan pemerintah akan memaksa seluruh produsen untuk mencantumkan label halal dan bagi produk yang tidak halal wajib mencantumkan informasi ketidakhalalan (Yuswohady.et al, 2014). 
Produk yang wajib dihalalkan tertera dalam Pasal 1 Ayat 1 UU JPH, yaitu barang dan atau jasa yang terkait dengan makanan, minuman, obat, kosmetik, produk kimiawi, produk biologi, produk rekayaasa genetik, serta barang gunaan yang dipakai, digunakan, atau dimanfaatkan oleh masyarakat. Di samping itu, dalam Pasal 1 Ayat 3 pemerintah juga menetapkan bahwa Proses Produk Halal (PPH) meliputi rangkaian kegiatan untuk menjamin kehalalan produk mencakup penyediaan barang, pengelolaan penyimpanan, pengemasan, pendistribusian, penjualan, dan penyajian produk. Artinya secara keseluruhan rantai nilai bisnis produk harus dijamin secara halal (Yuswohady.et al,.2014).

Fenomena produk halal dalam media iklan memberikan efek samping kepada masyarakat bahwa, sekarang ini produk halal seperti produk brand ternama consumer choise, top brand, dan superbrand. Dengan menjual imaji halal di media, maka akan menjadi elemen kunci sebagai indikator kelayakan suatu konsumsi produk dan menciptakan ketakutan serta ancaman palsu. Fenomena produk halal juga merambah ke pasaran fashion muslim. Tren fashion muslim mulai muncul sekitar tahuan 2000-an. Salah satu tren fashion muslim yang meroket adalah jilbab. Perkembangan tren fashion jilbab di Indonesia sangat pesat, sehingga mampu bersaing di kancah nasional maupun internasional.

Zoya adalah salah satu brand pioneer busana muslim dan jilbab di Indonesia. Berdiri sejak tahun 2005, dan telah memiliki lebih dari 160 toko. Pada tahun 2016, Zoya mendapatkan sertifikat dari MUI sebagai kerudung atau jilbab halal pertama di Indonesia dengan nomor sertifikasi 01171156041015. Iklan televisi Zoya mengkomodifikasi nilai agama melalui wacana hijab halal sebagi karakteristik terpenting, dengan tagline "Cantik, Nyaman, Halal".

Zoya mengajukan sertifikasi halal dari tahun 2015 lalu dan disetujui MUI Jabar tahun 2016. Hal ini menciptakan kontroversi yang mempertanyakan aspek halal dari produk. Terlepas dari kebutuhan masyarakat muslim untuk mencari produk halal dan kegunaan iklan sebagai komoditas pemasaran. Tidak seharusnya nilai halal tersebut dikomodifikasi dalam sebuah iklan komersil yang semata-mata untuk mencari keuntungan. Pernyataan bahwa produk Zoya jilbabnya halal, memicu reaksi banyak orang akan keraguan sebuah jilbab. Baik itu reaksi negatif atau positif di media sosial. 
Iklan televisi Zoya mengkomodifikasi nilai agama melalui wacana hijab halal sebagi karakteristik terpenting. Dengan tagine "Cantik, Nyaman, Halal" Zoya meanfaatkan kata dan lebel halal sebagai materi promosi. Kata halal dan sertifikasinya dijadikan legitimasi iklan untuk menyakinkan masyarakat bahwa produk yang dijual merupakan produk yang tepat untuk menjalankan perintah agama. Mengkomodifikasi nilai agama dengan kata halal di badan iklan dan di tegaskan oleh brand ambasador dengan tujuan mengedukasi umat muslim dalam menyempurnakan syariat agama dan menciptkan gaya hidup islami penyempurna agama, (Arianti dan Purnama, 2018).

Iklan televisi Zoya juga menampilkan gaya hidup modern, religius, santai dan realistis dengan memunculkan simbol yang modern dan mempresentasikan Islam, yang mana cenderung dikomodifikasi untuk keuntungan Zoya semata. Produk Zoya memiliki jenis modalitas epistemik dan jenis deontik tinggi dengan tujuan mempresentasikan umat Islam dan menciptakan urgensi agar penonton yang melihat iklan "Cantik, Nyaman, Halal" membeli jilbab halal sebagai penyempurna atau kepatuhan syariat Agama Islam. Dengan demikian, dapat dikatakan Zoya mengkomodifikasi iklannya dengan menggunkan nilai halal,(Arianti dan Purnama 2018). Penelitian ini melihat cara pandang atau resepsi perempuan muslim komunitas Solo Hijabers terkait dengan komodifikasi halal pada iklan jilbab Zoya. Sebagai komunitas Hijabers aktif dan penonton tentu dapat memberikan makna, mengenai penyampaian pesan iklan.

Penelitian Indhie Febrianti Herlina tentang Analisis Resepsi Perempuan Muslim Terhadap Komodifikasi Penggunaan Jilbab Dalam Iklan Wardah Versi True Colos Dewi Sandra Tahun 2016. Penelitian ini membahas tentang bagaimana cara pandang khalayak terhadap penggunaan jilbab yang ditampilkan dalam iklan Wardah versi "True Colour Dewi Sandra" dengan menggunakan teori Analisis Resepsi Struat Hall. Penulis mendeskripsikan bahwa resepsi perempuan muslim terbagi menjadi tiga bagian yaitu dominant hegemonic position, Negotiated position dan Oposisi. Hasil dari penelitian tersebut adalah $20 \%$ informan memilih sebagai negotiated position, $20 \%$ informan memilih menjadi hegemonic position dan $10 \%$ memilih menjadi oposisi.

Penelitian selanjutnya dari Madyawati, dengan judul “Analisis Resepsi Militerisme Dalam Film 3 Pada Forum Komunikasi Putra Putri Purnawirawan Indonesia 
Klaten". Penelitian ini merupakan studi tentang audiens dengan pendektan Resepsi. Tujuan penelitian ini untuk mengetahui pemaknaan anggota forum Komunikasi Purtra Putri Purnawirawan Indonesia terhadap Militerisme dalam film 3 (Alif Lam Mim). memiliki kekuatan sendiri dalam memaknai teks. Pembuatan teks yang disajikan produsen tidak dapat memaksa makna tertentu kepada audiens dan ini disebabkan karena latar belakang yang berbeda. Dalam hal ini Posisi Hegemoni Dominan dalam film 3 (Alif Lam Mim). Informan tidak ada yang memiliki pandangan yang sejalan dan menyetujui apa yang disampaikan dalam adeganadegan dalam film. Posisi Negosiasi ada 3 informan yang menerima sebagai pesan yang disampaikan dalam film. Dalam posisi Oposisi memiliki pemahaman yang bersebrangan dengan apa yang disampaikan dalam film 3 (Alif Lam Mim). Hasil penelitian menunjukkan bahwa bahwa audiens yang berbeda memaknai film secara berbeda-beda. Hal ini menunjukkan bahwa audiens memiliki kekuatan sendiri dalam memaknai teks. Pembuatan teks yang disajikan produsen tidak dapat memaksa makna tertentu kepada audiens dan ini disebabkan karena latar belakang yang berbeda. Dalam hal ini Posisi Hegemoni Dominan dalam film 3 (Alif Lam Mim). Informan tidak ada yang memiliki pandangan yang sejalan dan menyetujui apa yang disampaikan dalam adegan-adegan dalam film. Posisi Negosiasi ada 3 informan yang menerima sebagai pesan yang disampaikan dalam film. Dalam posisi Oposisi memiliki pemahaman yang bersebrangan dengan apa yang disampaikan dalam film 3 (Alif Lam Mim).

Sedangkan penelitian Irma Yanuaristi Penggunaan Label Halal Zoya Sebagai Strategi Komunikasi Pemasaran Zoya tahun 2017, penelitian ini membahas penggunaan label halal sebagai strategi pemasaran. Hasilnya menyimpulkan bahwa Zoya memunculkan label halal pada iklan televisi, spanduk, kartu anggota, X-banner, kata kunci kuis. Kemudian label halal juga diimplementasikan dalam beberapa kegiatan seperti hijab class, pemilihan Brand Ambassador, Zoya give away dan pesan broadcast. Label halal dalam strategi pemasaran dikemas menjadi sebuah bentuk pesan persuasi, yang bertujuan untuk meningkatkan penjualan serta dalam rangka menyadarkan masyarakat akan pentingnya memakai produk-produk halal. Selain itu, penggunaan label halal juga digunakan sebagai upaya membangun citra positif, yaitu membangun citra brand hijab yang nyaman, berkualitas dan terjamin dari segi bahan produk. 
Penelitian yang lain berasal dari penelitian Siti Maemonah tentang pengaruh Merek dan Labelisasi Halal Terhadap Keputusan Pembelian Produk Jilbab Zoya pada program Studi Ekonomi Islam, Universitas Islam Negeri Walisong. Tahun 2017. Penelitian ini untuk mengetahui seberapa besar pengaruh variabel independen yaitu merek (X1) dan labelisasi halal (X2) terhadap keputusan pembelian(Y) di outlet jilbab Zoya Pamularsih Semarang. Sampel yang diambil berjumlah 90 responden dari populasi konsumen di outlet jilbab Zoya Pamularsih Semarang dengan menggunakan teknik purposive sampling. Berdasarkan pengujian terhadap pengaruh positif dan signifikan antara variabel merek dan labelisasi halal terhadap keputusan pembelian konsumen. Berdasarkan pengujian, terhadap pengaruh positif dan signifikan antara variabel merek dan labelisasi halal terhadap keputusan pembelian.

Hal ini menunjukkan bahwa semakin tinggi citra merek dan labelisasi halal maka semakin tinggi keputusan pembelian. Hasil dari pengujian menunjukkan bahwa semua variabel yang digunakan memenuhi kriteria pengujian yang digunakan. Adapun hasil regresi berganda adalah: $Y=1,519+0,282+0,274$ Koefisien determinasinya (adjusted $R^{2}$ ) yang diperoleh sebesar 0,527. Hal ini berarti $52,7 \%$ keputusan pembelian dapat dijelaskan oleh variabel merek dan labelisasi halal, sedangkan 47,3\% keputusan pembelian dapat dijelaskan dari variabel lain selain kedua variabel yang digunakan dalam penelitian ini.

Penelitian dari Nurul Istiqomah tentang Mengungkap Mitos Simbol Halal Dalam Iklan Kerudung Zoya di Intagram Tahun 2016. Penelitian ini berangkat dari fenomena Zoya, mengunggah iklan yang memuat pernyataan tentang kerudung bersertifikat halal yang telah mendapatkan sertifikat dari Majelis Ulama Indonesia, melalui akun sosial media miliknya pada Februari 2016. Tujuan penelitian ini adalah untuk mengungkap mitos simbol halal dalam Iklan kerudung bersertifikat halal tersebut. Penelitian ini menggunakan pendekatan kualitatif dengan analisis semiotika versi Roland Barthes melalui tahapan analisis denotasi dan konotasi. Hasil penelitian ini menunjukkan bahwa simbol halal dalam iklan ini mengandung mitos nilai kebaikan dan keberkahan lebih yang akan didapatkan konsumen dibandingkan dengan kerudung biasa maupun kerudung merek lain yang tidak menggunakan label halal. Simbol halal dalam iklan ini dapat dikatakan telah mengalami komodifikasi, dengan asumsi produsen telah mengubah nilai guna 
"halal" menjadi nilai tukar ekonomis. Tujuan produsen menggunakan simbol halal dalam produknya mengarah ke konsumerisme, produsen ingin mendapatkan kepercayaan konsumen muslim yang melekat pada simbol halal, dan berakhir pada keputusan konsumen untuk melakukan pembelian produk Zoya. Penelitian Istiqomah membuktikan iklan halal mengalami komodifikasi sedangkan penulis membahas resepsi kelompok hijabers mengenai jilbab halal zoya apakah sesuai atau berbeda pendapat dengan tujuan maksud perusahaan.

Dari semua penelitian di atas menjelaskan bahwa Televisi menjadi salah satu media massa yang memiliki pengaruh terhadap khalayak. Banyaknya tayangan baik program maupun iklan dalam memaknai pesan (resepsi) khalayak akan berbeda satu dengan lainya. Munculnya tayangan iklan Zoya dengan tagline “Cantik, Nyaman, Halal” di Televisi (input). Menegaskan bahwa jilbab Zoya halal dan menciptakan komodifikasi iklan, yang mana berhasil memunculkan berbagai pandangan khalayak, baik pro atau kontra (output), termasuk komunitas Solo Hijabers. Pandangan atau pemaknaan khalayak yang muncul akan dijabarkan menggunakan teori resepsi Struat Hall.

\section{METODE PENELITIAN}

Penelitian ini merupakan penelitian deskripsi kualitatif. Penelitian ini menggunakan teknik pengumpulan data wawancara, observasi dan dokumentasi. Objek utama dari penelitian ini adalah Komodifikasi Halal pada Iklan jilbab Zoya "Cantik, Nyaman, Halal". Penelitian mendiskripsikan mengenai pandangan atau pemaknaan (resepsi) komunitas Solo Hijabers terhadap komodifikasi halal pada iklan jilbab Zoya "Cantik, Nyaman, Halal".

Subjek penelitian dalam penelitian ini adalah Komunitas Solo Hijabers. Anggota yang masih aktif dalam komunitas ini sekitar tiga puluhan dari sekitar dua ratus anggota pada awal terbentuknya. Informan dalam penelitian ini dipilih secara purposive dan bersifat snowball sampling. Sumber data yang digunakan dalam penelitian ini adalah data primer dan data sekunder. Data primer didapat dari hasil wawancara dengan komunitas Solo Hijaber. Sedangkan data sekundernya adalah media dan arsip arsip lain yang mendukung dalam penelitian ini.

\section{HASIL PENELITIAN DAN PEMBAHASAN}




\section{Komodifikasi Halal dalam Iklan Jilbab Zoya "Cantik, Nyaman, Halal" Melalui}

\section{Televisi}

Iklan televisi adalah realitas sosial bentukan media massa. Melalui iklan, dunia pertelevisian tanpa disadari telah menguasai jalan pikiran dan membangun teater dalam pikiran manusia. Masyarakat tidak sadar adanya komodifikasi dalam iklan, yang menggunakan nilai, budaya, dan agama. Komodifikasi adalah cara perusahaan untuk mengubah nilai guna suatu barang menjadi nilai ekonomis yang menguntungkan (Ibrahim \& Ahmad, 2014). Vincent Mosco menjelaskan tipe komodifikasi ada lima, komodifikasi isi, komodifikasi khalayak, komodifikasi tenaga kerja, komodifikasi nilai, dan komodifikasi masa kanak-kanak.

Iklan jilbab Zoya "Cantik, Nyaman, Halal" memasukkan nilai agama lewat wacana tentang hijab halal sebagai karakteristik utama. Dalam hal ini, budaya ikut memiliki peran penting dalam nilai kehidupan agama yang tanpa disadari akan berujung pada komodifikasi nilai. Komodifikasi nilai menurut Miller dalam (Ibrahin \& Akhmad, 2014), secara halus akan menjerat dalam sebuah jaringan tafsir konsumen dan keterlibatan dengan semua sistem nilai, termasuk agama. Iklan Zoya mengemas label halal sebagai promosi penjualan untuk masyarakat, karena agama memiliki daya tarik sebagai objek budaya yang berakar dalam imaji diri masyarakat konsumen. Seharusnya label halal Zoya yang di peroleh setelah melalui sertifikasi, tidak dimanfaatkan untuk promosi. Iklan jilbab Zoya“Cantik, Nyaman, Halal" berdurasi $15^{\text {ee }}$ (lima belas detik). Kontennya mengambarkan bahwa umat muslim yang baik akan memperhatikan apa yang di gunakannya. Termasuk yang paling menjadi fokus utama adalah kehalalan jilbabnya.

Iklan Zoya mengkomodifikasi nilai halal dalam iklannya dengan membentuk sebuah citra kepada konsumennya dengan menggunakan citra perempuan. Hal tersebut dapat dilihat dari iklan Zoya dengan menggunakan tiga artis muda, cantik, berbakat. Di dalam iklan tersebut menggambarkan bahwa umat muslim perempuan yang berhijab akan memiliki aura kecantikan yang lebih apabila menggunakan produk halal. Iklan Zoya juga menggunakan citra manfaat, di mana media iklan dapat mengubah nilai guna label halal menjadi nilai tukar yang menguntungkan. Citra manfaat dapat membuat penilaian yang lebih positif terhadap suatu produk sehingga dapat menciptakan kebutuhan (Bugin, 2006). Kata halal dijadikan kelegalan bagi iklan untuk menyakinkan masyarakat bahwa 
produk yang dijual merupakan produk yang tepat untuk menjalankan perintah agama.

Dalam iklannya, Zoya seakan mengkomunikasikan produknya kepada masyarakat bahwa dengan menggunakan jilbab halal maka seseorang akan terlihat cantik dan pemakai jilbabnya juga merasa nyaman. Konsumen juga ditawarkan diskon menggiurkan, dengan harga yang terjangkau masyarakat sudah bisa memiliki jilbab halal untuk dikenakan sehari-hari.

\section{Kehalalan Jilbab Zoya pada Iklan Menurut Komunitas Solo Hijabers}

Munculnya iklan Zoya menjadi sesuatu yang baru. Hal ini dikarenakan Zoya menjadi jilbab bersertifikasi halal pertama yang muncul di masyarakat. Selama ini tidak pernah ada wacana mengenai kehalalan suatu jilbab atau produk yang di kenakan masyarakat. Sehingga masyarakat luas tidak pernah terpikir apakah jilbab yang mereka pakai halal atau tidak. Munculnya iklan jilbab Zoya yang menyatakan kehalalannya, menjadi persoalaan yang kontroversial. Menimbulkan banyak respons masyarakat baik respon yang positif maupun negatif.

Penulis menggunakan analisis resepsi untuk melihat dan memahami respons, penerimaan, sikap, dan makna yang diproduksi atau dibentuk oleh penonton dalam sebuah tayangan media. Media mempunyai peran khusus dalam penyebaran informasi yang di asumsikan dapat memiliki potensi untuk membangkitkan kesadaran masyarakat tentang masalah-masalah kelas, kekuasaan, dan dominasi. Tayangan iklan televisi termasuk media yang dapat menciptakan, mempertanyakan, memproduksi, dan merubah budaya. Dengan melihat tayangan iklan, tanpa di sadari masyarakat dapat merubah pola hidup dan meniru konten iklan sesuai yang mereka lihat (Suciati, 2017).

Asumsi dasar dalam analisis resepsi adalah pada perbedaan khalayak. Baik pria atau wanita dalam mengonsumsi informasi atau dalam memilih media. Sebagaimana yang dijelaskan Struat Hall, resepsi yaitu bagaimana proses pengkodean (encoding-decoding) penonton berlangsung di dalam media, memiliki respons yang berubah-ubah sesuai dengan kondisi. Kegiatan penerimaan pesan di lakukan dengan pengkodean encoding oleh pengirim dan diterjemahkan decoding oleh penerima. Encoding dalam proses komunikasi dapat berlangsung satu kali namun dapat terjadi berkali-kali. Sedangkan decoding adalah kegitan untuk 
menterjemahkan atau menginterpretasikan pesan-pesan fisik kedalam suatu bentuk yang memiliki arti bagi penerima, (Lestari, 2017). Menurut Hall, khalayak melakukan decoding terhadap pesan media melalui tiga kemungkinan posisi, yaitu:

Pertama, posisi hegemoni dominan adalah disaat khalayak menangkap dan menyetujui pesan iklan tersebut dengan baik, sesuai dengan maksud pengiklan tanpa mempertanyakan lagi tujuan dari iklan tersebut (Morisson, 2014). Untuk posisi hegemoni dominan dalam komodifikasi halal pada iklan jilbab Zoya, menunjukkan ada yang memiliki pemahaman yang sejalan dan meyetujui apa yang dimaksudkan tayangan iklan Zoya "Cantik, Nyaman, Halal”.

Kedua, posisi negosiasi. Morissan (2014:551), posisi di mana khalayak secara umum menerima ideologi dominan namun menolak penerapannya dalam kasuskasus tertentu. Dalam hal ini, khalayak bersedia menerima ideologi dominan bersifat umum, namum mereka akan melakukan beberapa pengecualian dalam penerapan yang disesuaikan dengan aturan budaya setempat. Dapat dikatakan posisi negosiasi adalah percampuran elemen adaptif dan oposisional, yang membentuk seseorang melakukan persyaratan tertentu sesuai dengan keinginan mereka dan melakukannya, namun pada dasarnya mereka menerima pesan yang disampaikan (Prayoga, Setiawan \& Aji, 2013). Informan yang berada dalam posisi negosiasi menerima hanya sebagian pesan yang dimaksudkan oleh iklan jilbab halal Zoya "Cantik, Nyaman, Halal" sebagai komodifikasi, sesuai dengan pandangan masing- masing. Posisi negosiasi dalam teori yang disampaikan Struat Hall ini informan menerima pesan yang disampaikan iklan jilbab Zoya namun menolak atau mengecualikan dalam hal tertentu. Untuk komodifikasi halal pada iklan jilbab Zoya dikatakan dalam posisi negosiasi. Hal ini dapat dilihat jawaban informan yang cenderung setuju akan tetapi tidak sepenuhnya setuju dengan iklan Zoya yang menggunakan kata halal. Informan cenderung setuju karena penggunaan label halal dalam sebuah iklan merupakan kebebasan perusahaan dalam mengubah nilai halal sebagai nilai ekonomis. Akan tetapi disamping itu semua informan juga berfikir bahwa semua jilbab pada dasarnya halal. Oleh karena itu dapat disimpulkan bahwa komunitas Solo Hijabers secara tidak langsung mengakui bahwa terdapat komodifikasi halal pada iklan Zoya.

Ketiga, posisi oposisi. Menurut Morissan (2014) cara terakhir yang dilakukan khalayak dalam melakukan decoding terhadap pesan media adalah melalui 
"oposisi" yang terjadi ketika khalayak audiensi yang kritis mengganti atau mengubah pesan atau kode yang disampaikan media dengan pesan atau kode alternatif. Audiensi menolak makna pesan yang dimaksud atau disukai media dan menggantikannya dengan cara berpikir mereka sendiri terhadap topik yang disampaikan media. Untuk posisi oposisi dalam iklan jilbab Zoya terkait nilai halalnya, tidak ada informan yang memiliki pendapat berbeda atau menolak konten yang disampaikan produsen (iklan jilbab halal Zoya). Dengan demikian secara jelas bahwa komunitas Solo Hijabers terpengaruh iklan Jilbab Zoya dan secara tidak langsung menyetujui nilai halal pada iklan jilbab Zoya sebagai bentuk komodifikasi. Meskipun informan tidak memiliki sikap, pemaknaan, dan bertindak dengan cara yang sama mereka tetap mendukung kebijakan pihak Zoya, yang menyatakan bahwa jibab Zoya Halal dan mendukung peredarannya di pasaran. Bahkan mereka ada keinginan membeli atau memakai jilbab halal Zoya.

\section{KESIMPULAN DAN SARAN}

\section{Kesimpulan}

Berdasarkan penjabaran di atas, terdapat tiga tipe dalam penerimaan pesan, yaitu hegemoni dominan, negosiasi, dan oposisi. Hasil penelitian ini hanya menunjukkan dua tipe saja yang diperoleh peneliti yaitu hegemoni dominan dan negosiasi. Sedangkan posisi oposisi tidak terjadi terhadap komunitas Solo Hijabers. Dengan demikian, produsen pembuat iklan Zoya telah berhasil dalam mempersuasi Solo Hijabers, dengan cara mengajak, mengerti, menyadari, bersikap, mengubah budaya sesuai dengan yang dikehendaki oleh pembuat konten dalam iklan jilbab Zoya "Cantik, Nyaman, Halal".

Penelitian ini menemukan sesuatu yang menarik dari informannya. Meskipun informan tidak memiliki sikap, pemaknaan, dan bertindak dengan cara yang sama. Mereka tetap mendukung kebijakan pihak Zoya, yang menyatakan bahwa hijab Zoya halal dan mendukung peredarannya di pasaran. Bahkan mereka ada keinginan membeli atau memakai jilbab halal Zoya. Di sini, tanpa sadar mereka menyetujui nilai halal pada iklan jilbab Zoya adalah bentuk komodifikasi.

\section{Saran}

UU jaminan produk halal (JPH) No 33 tahun 2014 dalam pasal 4 disebutkan 
bahwa seluruh produk masuk, beredar, diperdagangkan di wilayah Indonesia harus bersertifikasi halal. Untuk itu akan banyak iklan televisi dan media massa lainya memasukkan nilai, budaya, agama di komoditas sebagai strategi pemasaran produk.

Para pengguna media massa hendaklah lebih bijak dalam memahami konten iklan yang disampaikan di media, sebab media memiliki sifat mempengaruhi dan berimbas pada pemaknaan khalayak.

Bagi peneliti selanjutnya, penelitian ini masih berpotensi untuk dikembangkan. Terkait analisis resepsi maupun komodifikasi terhadap audien, sebaiknya dengan menggunakan metode kualitatif. Karenanya, diketahui maksud dan tujuan penelitian secara mendalam.

\section{DAFTAR PUSTAKA}

Arianti, R. T \& Purnama, H. (2018). Komodifikasi Kata Halal pada Iklan Hijab Zoya Versi Cantik Nyaman Halal. Jurnal Ilmiah LISKI (Lingkar Studi Komunikasi), Vol.4 No.2.

Arifin, F. (2019). Mubalig Youtube dan Komodifikasi Konten Dakwah. al-Balagh: Jurnal Dakwah dan Komunikasi, Vol. 4 No. 1

Biagi, S. (2010). Media/Impact Pengantar Media Massa. Jakarta: Salemba Humanika.

Herlina, I. F. (2016). Analisis Resepsi Perempuan Muslim Terhadap Komodifikasi Penggunaan Jilbab Dalam Iklan Wardah Versi True Colors-Dewi Sandra. Skripsi: Universitas Andalas Padang.

Istiqomah, N. (2016). Mengungkap Mitos Simbol Halal Dalam Iklan Kerudung Zoya di Intagram. Penelitian ini berangkat dari fenomena Zoya. Skripsi: Universitas Diponegoro Semarang.

Madyawati. (2017). Analisis Resepsi Militerisme Dalam Film 3 Pada Forum Komunikasi Putra Putri Purnawirawan Klaten. Skripsi: Intitut Agama Islam Negeri Surakarta.

Maemonah, S. (2017). Pengaruh Merek dan Labelisasi Halal Terhadap Keputusan Pembelian Produk Jilbab Zoya (studi kasus pada Komsumen di Outlet Produk Jilbab Zoya Pamularsih Semarang). Skripsi: Universitas Islam Negeri Walisongo Semarang.

Mulyana, D. (2001). Metode Penelitian Kualitatif: Paradigma Baru Ilmu Komunikasi dan Ilmu Sosial. Bandung: PT Remaja Rosdakarya.

Subandy,I. (2007). Kecerdasan Komunikasi Seni Berkomunikasi Kepada Publik. Bandung: Simbiosa Rekatama Media.

Sugiyono. (2018). Metode Penelitian Kuantitatif, Kualitatif, dan RED. Bandung: Alfabeta

Yanuaristi, I. (2017). Penggunaan Label Halal Sebagai Strategi Komunikasi Pemasaran Zoya. Skripsi: Universitas Sultan Ageng Trirtayasa Serang. 
Yusuf, M. F. (2016). Komodifikasi: Cermin Retak Agama di Televisi Perspektif Ekonomi Politik Media. INJECT: Interdisciplinary Journal of Communication. Vol. 1, No.1

Yuswohady.et al,. (2017).Gen M: Generation Muslim.Yogyakarta: PT Bentang Pustaka. 